\title{
Controls of the landfast ice-ocean ecosystem offshore Barrow, Alaska
}

\author{
Meibing JIN, ${ }^{1}$ Clara J. DEAL, ${ }^{1}$ Jia WANG, ${ }^{1}$ Kyung-Hoon SHIN,${ }^{2}$ Nori TANAKA, ${ }^{1,3}$ \\ Terry E. WHITLEDGE, ${ }^{4}$ Sang Heon LEE, ${ }^{4}$ Rolf R. GRADINGER ${ }^{4}$ \\ ${ }^{1}$ International Arctic Research Center, University of Alaska Fairbanks, PO Box 757340, Fairbanks, AK 99775-7340, USA \\ E-mail: mjin@iarc.uaf.edu \\ ${ }^{2}$ Hanyang University, Ansan 426-793, Republic of Korea \\ ${ }^{3}$ Institute of Observational Research for Global Change, Japan Agency for Marine-Earth Science and Technology, \\ Yokosuka 237-0001, Japan \\ ${ }^{4}$ Institute of Marine Science, University of Alaska Fairbanks, Fairbanks, AK 99775-7220, USA
}

\begin{abstract}
Ba sed on biophysical ice-core data collected in the landfast ice off Barrow, Alaska, USA, in 2002 and 2003, a one-dimensional ice-ocean ecosystem model was developed to determine the factors controlling the bottom-ice algal community. The data and model results revealed a three-stage ice-algal bloom: (1) onset and early slow growth stage before mid-March, when growth is limited by light; (2) fast growth stage with increased light and sufficient nutrients; and (3) decline stage after late May as ice algae are flushed out of the ice bottom. Stages 2 and 3 are either separated by a transition period as in 2002 or directly connected by ice melting as in 2003, when in situ light and nutrient enrichment experiments showed only light limitations. The modeled net primary production of ice algae (NPP ${ }^{A i}$ ) from March to June is 1.2 and $1.7 \mathrm{~g} \mathrm{C} \mathrm{m}^{-2}$ for 2002 and 2003, respectively, within the range of previous observations. Model sensitivity studies found that overall NPP ${ }^{A i}$ increased almost proportionally to the initial nutrient concentrations in the water column. A phytoplankton bloom (if it occurs as in 2002) would compete with ice algae for nutrients and lead to reduced $\mathrm{NPP}^{\mathrm{Ai}}$. About $45 \%$ of the $\mathrm{NPP}^{\mathrm{Ai}}$ was exported to the shallow benthos.
\end{abstract}

\section{INTRODUCTION}

Sea-ice algae in the bottom skeletal ice layer play a critical role in polar marine ecology (Arrigo, 2003) and, along with phytoplankton, provide an important source of primary production in both the Arctic (Alexander and others, 1974; Horner and Schrader, 1982) and Antarctic Oceans (Arrigo and others, 1997). Although primary production of sea-ice algae is generally low compared to their phytoplankton counterparts, they are often virtually the sole source of fixed carbon for higher trophic levels in ice-covered waters, and sustain a wide variety of organisms through the ice-covered period (Schnack-Schiel, 2003). The contribution of sea-ice algae to total primary production can be as much as $60 \%$ (Horner and Schrader, 1982; Gosselin and others, 1997) in some regions of the Arctic.

The controls of the sea-ice ecosystem are still poorly understood compared to those of the water-column ecosystem, due to sparse observations and complexities involving a number of environmental factors, such as ice types and the patchiness of snow- and ice-thickness distribution, temperature, salinity, light and nutrients. In addition to observations, ecosystem models are an important tool for understanding and determining the processes and controls of the ecosystem. Using ecosystem models has been a common practice in the study of sea-water ecosystems, but such models have been applied to very few sea-ice habitats. The growth behavior of the algal community in the fast ice of McMurdo Sound, Antarctica, has been simulated by one-dimensional (1-D) ice ecosystem models developed by Arrigo and others (1993) and Arrigo and Sullivan (1994). Primary production of the Antarctic Ocean was estimated by applying the model to distinct locations (Arrigo and others, 1997). Nishi and Tabeta (2005) developed a coupled ice-ocean ecosystem model to study the contribution of ice algae to the ice-covered ecosystem of Saroma lake, Japan, and found that ice algae released from the ice are rapidly exported because of their high sinking speed and the shallow depth of the lake. Carbon flows through the microbial food web of first-year ice in Resolute Passage, Canadian High Arctic, were inferred using an inverse model by Vézina and others (1997). A coupled snow-ice-ice-algae model was developed to investigate the importance of different ice-algal growth limitation terms, as well as different loss terms, in regulating the ice-algal biomass accumulation at the bottom of landfast ice in the Canadian Arctic Archipelago by Lavoie and others (2005).

The ice-algal community of the Chukchi Sea, Alaska, USA, was observed in 1972 and 1973 (Alexander and others, 1974), but rarely thereafter. These early observations have attracted renewed attention in recent years because of concerns over Arctic climate warming which is predicted to be more rapid and important than in other regions of the globe. Researchers supported by the International Arctic Research Center (IARC), University of Alaska Fairbanks, collected a series of ice-core data offshore from Barrow where important land-based logistic support is available to access the sea ice. In this study, these data are analyzed along with other observations of snow and ice depth collected by other research groups in the same area, during the same time period. A 1-D sea-ice ecosystem model was developed and added to the existing ocean-based IARC Physical Ecosystem Model (PhEcoM; Wang and others, 2003; Jin and others, 2006) to investigate the controls of the ice-algal community in the fast ice off the Barrow coast. 


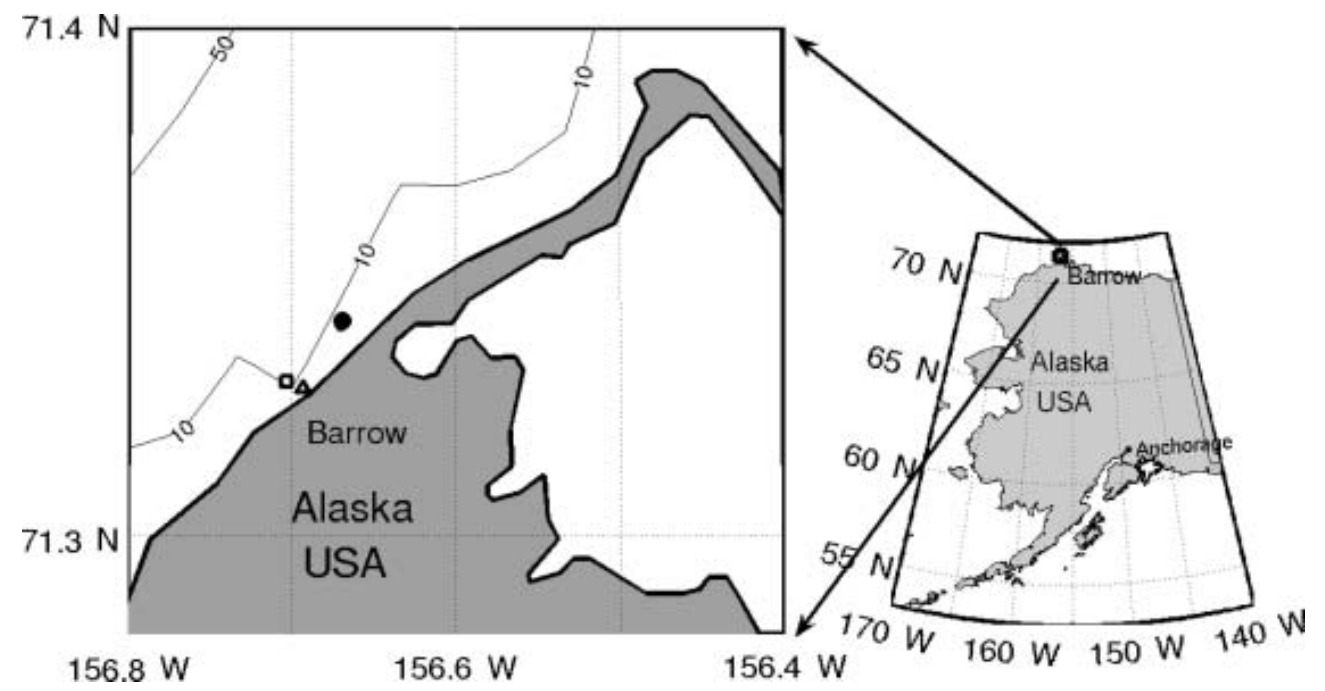

Fig. 1. The ice-core sampling sites. Square: IARC site $\left(71^{\circ} 9.6^{\prime} \mathrm{N}, 156^{\circ} 42.2^{\prime} \mathrm{W}\right)$; triangle: IMS site $\left(71^{\circ} 19.7^{\prime} \mathrm{N}, 156^{\circ} 41.6^{\prime} \mathrm{W}\right)$; solid circle: APL site $\left(71^{\circ} 20.5^{\prime} \mathrm{N}, 156^{\circ} 40.1^{\prime} \mathrm{W}\right)$ and $\mathrm{Gl}$ site $\left(71^{\circ} 20.5^{\prime} \mathrm{N}, 156^{\circ} 40.2^{\prime} \mathrm{W}\right.$, overlapped with $\mathrm{APL}$ site). Contour lines are water depth in meters from the US National Geophysical Data Center's ETOP2.

Because advection is unaccounted for in the 1-D model, more attention in this study is given to the sea-ice algae that are stably attached to the fast ice.

\section{OBSERVATIONS}

A series of ice-core observations was made approximately $1 \mathrm{~km}$ offshore from the Chukchi Sea side of the Barrow coast (Fig. 1) by scientists from the IARC, the Institute of Marine Science (IMS; Gradinger and Bluhm, 2004), the Geophysical Institute (Gl; Eicken and others, 2004), University of Alaska Fairbanks, and the Applied Physics Laboratory (APL), University of Washington (C. Krembs, unpublished data), from spring (March-June) 2002 to spring 2003. The variables measured are listed in Table 1.

\section{PHYSICAL ENVIRONMENT}

The Arctic sea-ice cover is spatially variable, consisting of leads, first-year ice and multi-year ice. The ice type can be classified as clean (no visible coloration by sediment) or sediment-laden; coloration is a key factor in determining albedo and light attenuation in the ice. The ice-core sampling sites near Barrow (Fig. 1) consist of continuous first-year fast ice. Clean ice samples were collected from areas of level shore-fast ice. The water column depth was approximately $6 \mathrm{~m}$. An active pressure ridge occurred about
$1 \mathrm{~km}$ further out where the water depth was $10 \mathrm{~m}$ (Alexander and others, 1974). A lead of varying size was located beyond the pressure ridge, even in winter. Sea-ice cover usually starts to form in the fall and becomes fast ice in the winter.

Ice thickness was measured from the ice-core samples except for the data from the Gl site, which were measured with a combination of an ablation stake and a hot-wire icethickness gauge, as described in detail in Perovich and others (2003) and Eicken and others (2004). During the icealgal bloom period (March to early June) of 2002 and 2003, ice thickness (Fig. 2) was $1.2-1.8 \mathrm{~m}$ with maxima in midMay, followed by melting.

Snow depth fluctuated between 10 and $15 \mathrm{~cm}$ for the winter months until mid-May for both years. In 2002, 10 days after the snow melted, the ice thickness started to decrease, due to typical surface melting triggered by increasing solar radiation. Temperatures in the sea ice at the IARC site in 2002 are shown in Figure 3a.

In 2002 the ice surface temperature increased from $-18^{\circ} \mathrm{C}$ on 4 March to $-8^{\circ} \mathrm{C}$ on 1 May, when the ice was growing and the bottom-ice temperature was at the freezing point. The ice surface temperature was near ice-melting temperature between the 22 May and 5 June visits. The slightly higher than $0^{\circ} \mathrm{C}$ ice temperatures at the bottom or surface in Figure 3a might be due to the influence of water or air temperature during the measurement and refer to near-icemelting temperature in the paper. The temperature in the

Table 1. Variables measured on the fast ice near Barrow

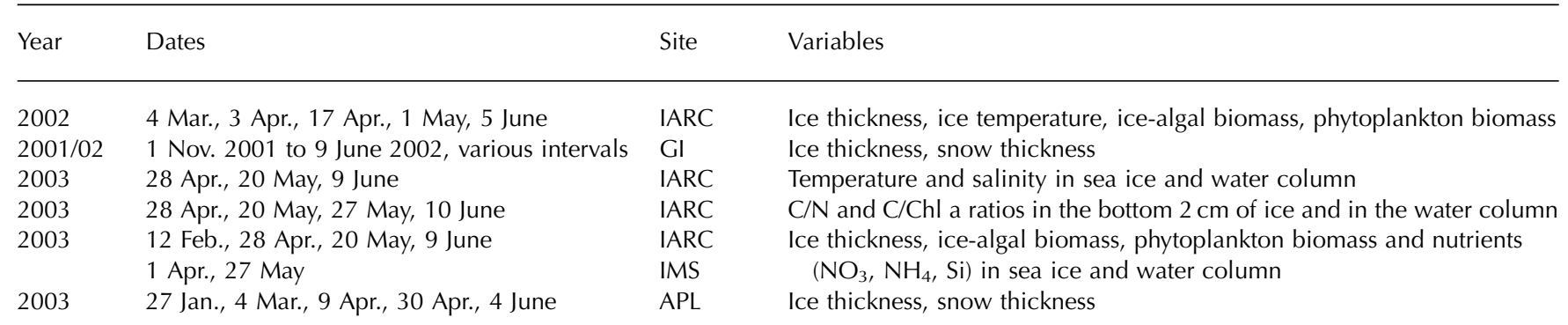



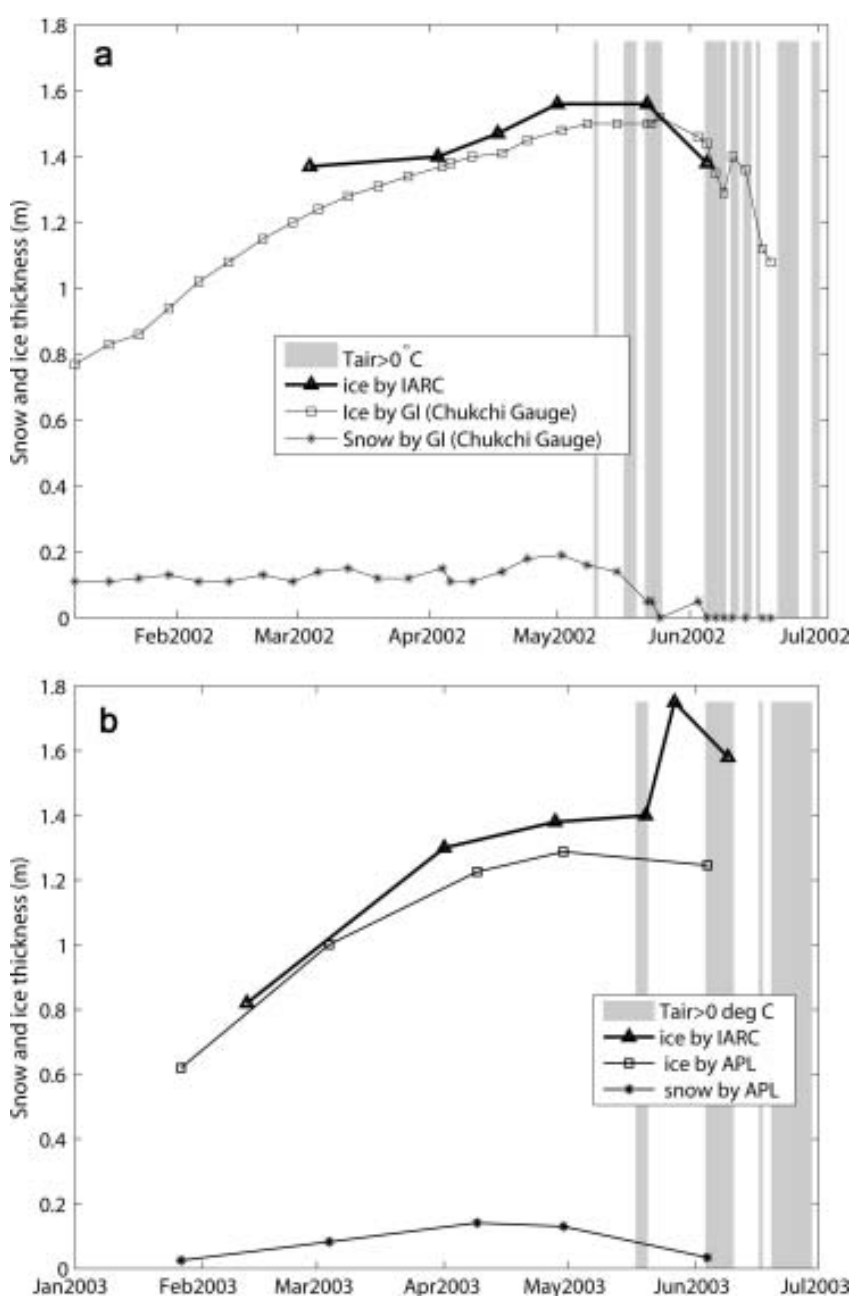

Fig. 2. (a) Observed ice thickness at IARC site and snow and ice thickness at GI site in 2002. (b) Observed ice thickness at IARC site and snow and ice thickness at APL site in 2003.

middle of the sea ice increased from $-1.2^{\circ} \mathrm{C}$ to $-0.4^{\circ} \mathrm{C}$, and the bottom-ice temperature increased from $-0.3^{\circ} \mathrm{C}$ to around melting temperature. This suggests that there might have been some ice bottom ablation along with surface melting.

In 2003, both temperature and salinity in the sea ice and water column were observed on only three occasions (Fig. 4). The sea-ice temperature in 2003 was cooler than in the same period in 2002. Salinity in both the sea ice and the top layer of the water column decreased on 9 June, coincident with an increase of temperature in both the sea ice and water column (Fig. 4).

\section{ECOSYSTEM MODEL (IARC PhEcoM)}

The ecosystem model consists of physical and biological submodels for the water column and sea ice. The two submodels interact through nutrient transport between the water and ice at the ice-water interface, and ice algae that are released into the water column.

The 1-D physical and biological models in the water column are described in detail in Jin and others (2006). Since the study area is fully covered by fast ice during the model period (March-June), the water temperature is considered constant at the freezing point. The biological model for the water column has nine compartments: two phytoplankton (diatom and flagellates: D and F), three zooplankton (small
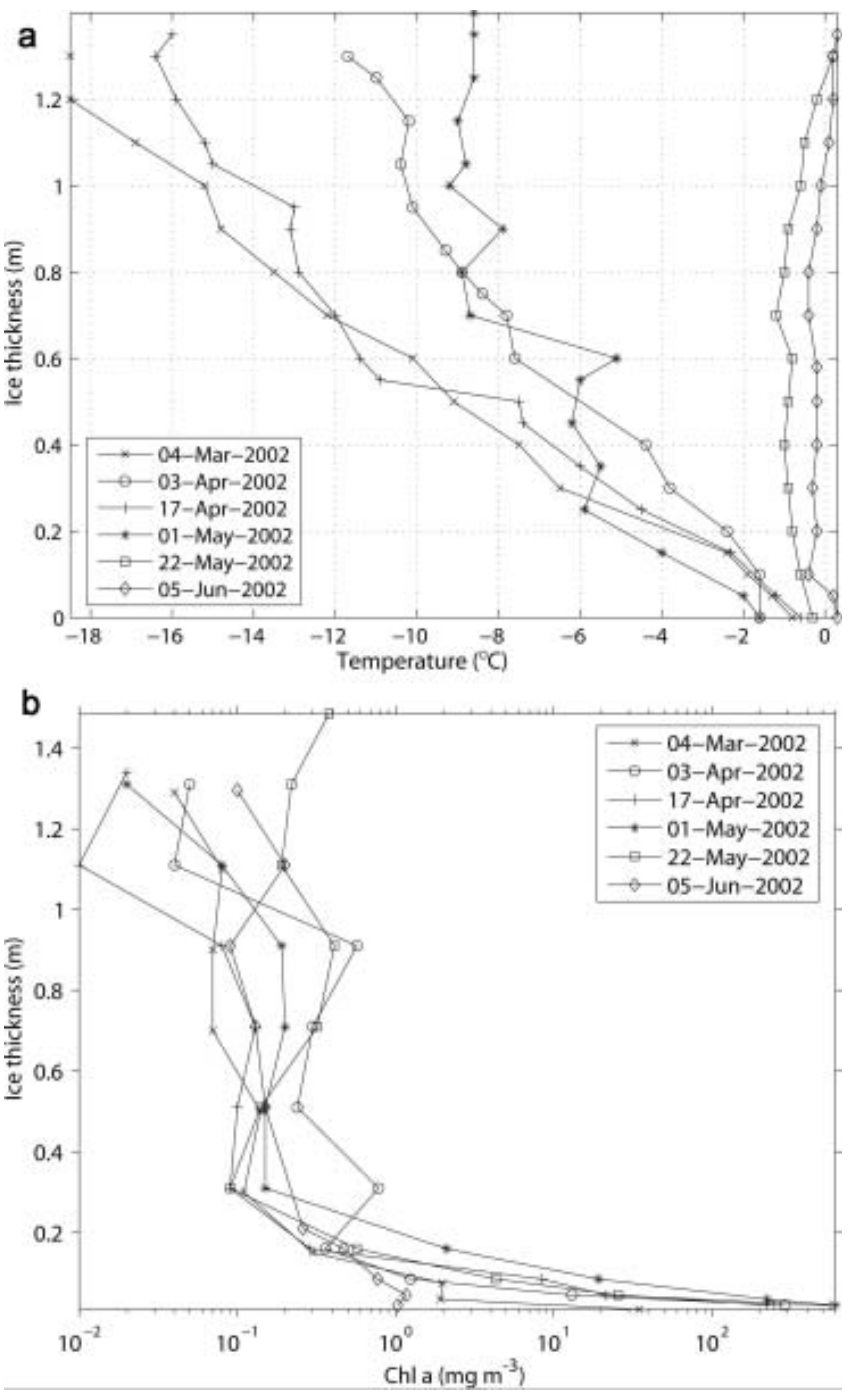

Fig. 3. Observed (a) ice temperature and (b) ice-algae distribution in sea ice at IARC site in 2002.

copepods, large copepods, and microzooplankton: ZS, ZL, $\mathrm{ZP}$ ), three nutrients (nitrate+nitrite, ammonium, silicon: $\mathrm{NO}_{3}, \mathrm{NH}_{4}, \mathrm{Si}$ ) and detritus (Det).

The sea-ice ecosystem model focuses on the bottom $2 \mathrm{~cm}$ skeletal layer as shown in the observed profiles in sea ice (Fig. 3b). Generally speaking, the greatest biomass fraction of sea-ice algae resides in the bottom layer of sea ice because of the stable environment that is favorable for growth. The upward distribution of ice algae is limited by nutrient availability and the high brine salinity characteristic of the sea-ice interior when temperatures are low (Arrigo and Sullivan, 1992). Platelet ice is uncommon in the Arctic (Dieckmann and Hellmer, 2003) and was not observed in the study area; thus, it is not considered in this study.

Due to lack of observations, Arrigo and others (1993) parameterized zooplankton grazing in a similar mathematical form as respiration, which is actually equivalent to increasing the respiration coefficient. In this study, the grazing term in sea ice is not included in the equations, because the grazing pressure of sea-ice meiofauna is low compared to daily primary production rates of $<5 \% \mathrm{~d}^{-1}$ (Gradinger, 1999; Michel and others, 2002). Similarly, grazing impact on the ice-algal standing stock at the ice underside in summer is low (e.g. 1.1\% in the Laptev Sea and 

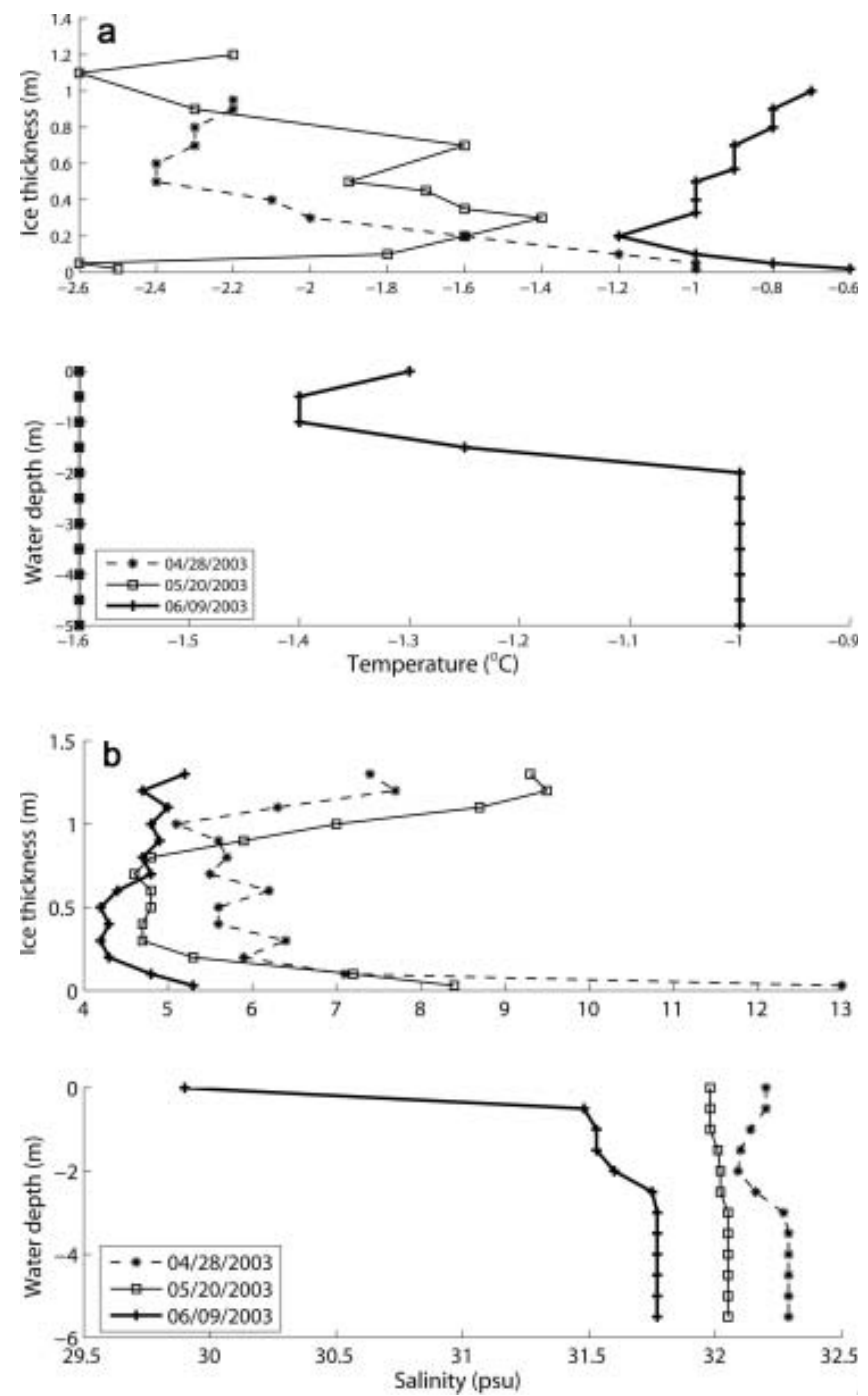

Fig. 4. Observed (a) temperature in sea ice and water and (b) salinity in sea ice and water at IARC site in 2003. Dates are $\mathrm{mm} / \mathrm{dd} /$ yyyy.

$2.6 \%$ in the Greenland Sea (Werner, 1997)). The observed ice thickness and temperature are interpolated to each timestep instead of being determined by an ice thermodynamic model. The coupled ice-ocean ecosystem model flowchart is shown in Figure 5. The biological dynamics in the sea ice are expressed as follows:

$$
\begin{aligned}
\frac{\partial \mathrm{Ai}}{\partial t}= & \mathrm{Ai}\left(G^{\mathrm{Ai}}-R^{\mathrm{Ai}}-\mathrm{Rg}^{\mathrm{Ai}}\right)+\frac{\partial\left(T_{\mathrm{wi}}-W^{\mathrm{Ai}}\right) \mathrm{Ai}}{\partial z} \\
& +\frac{\partial}{\partial z}\left(K_{\mathrm{wi}} \frac{\partial \mathrm{Ai}}{\partial z}\right) \\
\frac{\partial \mathrm{NO}_{3}}{\partial t}= & N_{\mathrm{Nit}}\left[\mathrm{NO}_{3}^{\mathrm{Ai}}\right]-f_{\mathrm{NO}_{3}} \mathrm{Ai}\left(G^{\mathrm{Ai}}-R^{\mathrm{Ai}}\right)+\frac{\partial T_{\mathrm{wi}} \mathrm{NO}_{3}}{\partial z} \\
& +\frac{\partial}{\partial z}\left(K_{\mathrm{wi}} \frac{\partial \mathrm{NO}_{3}}{\partial z}\right) \\
\frac{\partial \mathrm{NH}_{4}}{\partial t}= & \mathrm{Ai} \operatorname{Rg}^{\mathrm{Ai}}-\left(1-f_{\mathrm{NO}_{3}}\right) \mathrm{Ai}\left(G^{\mathrm{Ai}}-R^{\mathrm{Ai}}\right)-N_{\mathrm{Nit}}\left[\mathrm{NH}_{4}^{\mathrm{Ai}}\right] \\
& +\frac{\partial T_{\mathrm{wi}} \mathrm{NH}_{4}}{\partial z}+\frac{\partial}{\partial z}\left(K_{\mathrm{wi}} \frac{\partial \mathrm{NH}}{\partial z}\right) \\
\frac{\partial \mathrm{Si}}{\partial t}= & -k_{\mathrm{Si}} \mathrm{Ai}\left(G^{\mathrm{Ai}}-R^{\mathrm{Ai}}\right)+\frac{\partial T_{\mathrm{wi}} \mathrm{Si}}{\partial z}+\frac{\partial}{\partial z}\left(K_{\mathrm{wi}} \frac{\partial S \mathrm{i}}{\partial z}\right)
\end{aligned}
$$

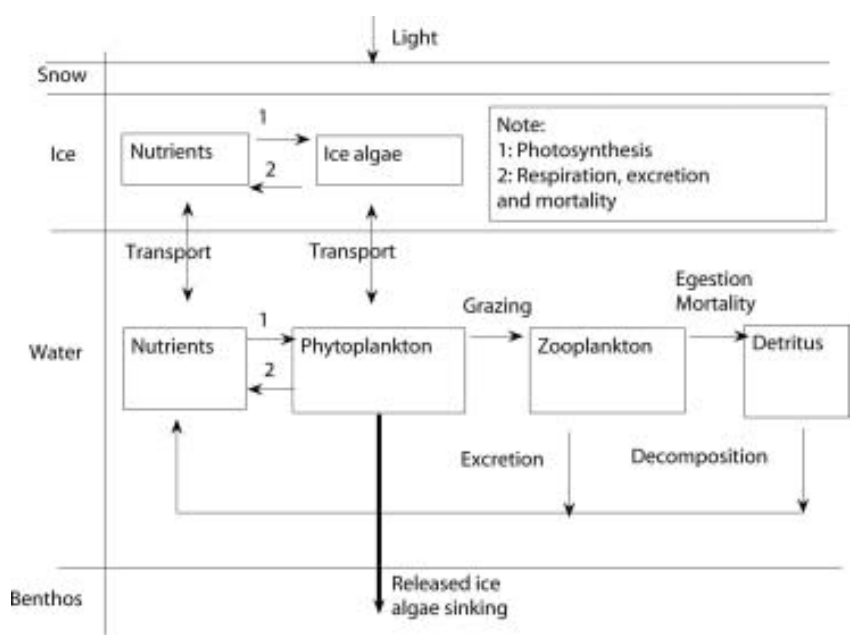

Fig. 5. Coupled ice-ocean ecosystem model flow chart.

where $\mathrm{Ai}$ denotes ice-algal biomass in units of $\mathrm{mmol} \mathrm{N} \mathrm{m}^{-3}$, and $\mathrm{NO}_{3}, \mathrm{NH}_{4}$ and $\mathrm{Si}$ are nutrients in units of $\mathrm{mmol} \mathrm{N} \mathrm{m}^{-3}$, mmol $\mathrm{N} \mathrm{m}^{-3}$ and $\mathrm{mmol} \mathrm{Si} \mathrm{m}{ }^{-3}$, respectively. $N_{\text {frac, }} \mathrm{Si}_{\text {frac }}$ and $I_{\text {frac }}$ are ratios expressing nitrogen, silicon and light limitation. Term $\xi$ is an empirical salinity-dependent ice-algal growth rate calculated as in Arrigo and Sullivan (1992). Terms $G^{\mathrm{Ai}}, R^{\mathrm{Ai}}$ and $\mathrm{Rg}^{\mathrm{Ai}}$ are phytoplankton growth rate, respiration rate and mortality rate, respectively.

$$
\begin{aligned}
G^{\mathrm{Ai}} & =\mu_{0}^{\mathrm{Ai}} \mathrm{e}^{0.0633 T_{\mathrm{i}}} \times \min \left(N_{\text {frac }}, \mathrm{Si}_{\text {frac }}, I_{\text {frac }}\right) \xi \\
R^{\mathrm{Ai}} & =0.05 \mu_{0}^{\mathrm{Ai}} \mathrm{e}^{r T_{\mathrm{i}}} \\
\mathrm{Rg}^{\mathrm{Ai}} & =\operatorname{Rg}_{0} \mathrm{e}^{r_{g} T_{\mathrm{i}}} \\
N_{\text {frac }} & =\frac{\mathrm{NO}_{3}}{K_{\mathrm{SNO}_{3}}+\mathrm{NO}_{3}} \mathrm{e}^{-\psi \mathrm{NH}_{4}}+\frac{\mathrm{NH}_{4}}{K_{\mathrm{SNH}_{4}}+\mathrm{NH}_{4}} \\
\mathrm{Si}_{\text {frac }} & =\frac{\mathrm{Si}}{K_{\mathrm{SSi}}+\mathrm{Si}} \\
I_{\text {frac }} & =\left(1-\mathrm{e}^{-l \alpha / P_{\max }}\right) \mathrm{e}^{-l \beta / P_{\max }} \\
f_{\mathrm{NO}_{3}} & =\frac{\mathrm{NO}_{\mathrm{SNO}_{3}}+\mathrm{NO}_{3}}{\mathrm{~N}_{\text {frac }}} \mathrm{e}^{-\psi \mathrm{NH}_{4}}
\end{aligned}
$$

where $T_{\mathrm{i}}$ is the temperature in the bottom $2 \mathrm{~cm}$ skeletal layer. Brine flux volume in the skeletal layer has a high correlation $\left(R^{2}=0.994\right)$ with ice growth rate $\left(\mathrm{d} H_{\text {ice }} / \mathrm{d} t\right)$ during the ice growth period (Wakatsuchi and Ono, 1983). The water-ice interface transport, $T_{\text {wi }}$, is therefore calculated using this relationship, as in Arrigo and others (1993):

$$
\begin{aligned}
T_{\mathrm{wi}}= & C_{\mathrm{wi}}\left[9.667 \times 10^{-11}+4.49 \times 10^{-6} \frac{\mathrm{d} H_{\text {ice }}}{\mathrm{d} t}\right. \\
& \left.-1.39 \times 10^{-5}\left(\frac{\mathrm{d} H_{\text {ice }}}{\mathrm{d} t}\right)^{2}\right],
\end{aligned}
$$

where the coefficients have been adjusted for metric units and $T_{\mathrm{wi}}$ is expressed in units of $\mathrm{ms}^{-1}$. $C_{\mathrm{wi}}$ is a constant coefficient which is a combination of many factors, such as the fraction of the skeletal layer that is open to convection, layer depth, etc. Its value was determined according to model-data comparison. In this study, $C_{w i}$ is 72 during ice growth and 720 during ice melt. During the ice-melting period, there are no data available to make a polynomial 
Table 2. List of parameter values and conversion ratios

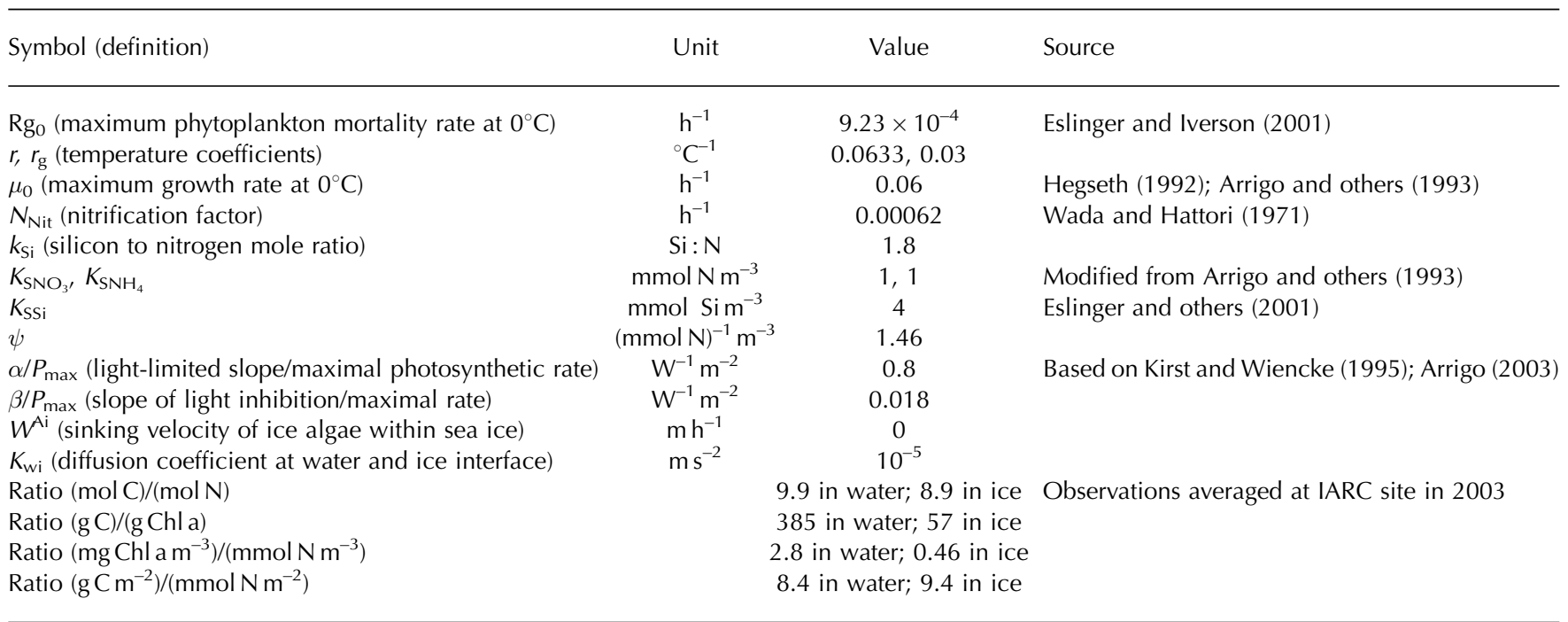

curve fit similar to Equation (11a). According to model sensitivity studies discussed later, we proposed an equation as below:

$$
T_{\mathrm{wi}}=C_{\mathrm{wi}}\left[4.49 \times 10^{-6} \frac{\mathrm{d} H_{\text {ice }}}{\mathrm{d} t}-1.39 \times 10^{-5}\left(\frac{\mathrm{d} H_{\text {ice }}}{\mathrm{d} t}\right)^{2}\right] \text {. }
$$

The light intensity, $I$, is calculated as in Jin and others (2006) using US National Centers for Environmental Prediction (NCEP) cloud cover and specific humidity data. Light attenuation coefficients are $20 \mathrm{~m}^{-1}$ for snow, $5 \mathrm{~m}^{-1}$ for the top $10 \mathrm{~cm}$ of ice and $1 \mathrm{~m}^{-1}$ for ice below $10 \mathrm{~cm}$ (based on Perovich 1996). The ice-algae self-shading coefficient is $0.005 \mathrm{~m}^{2}(\mathrm{mmol} \mathrm{N})^{-1}$. Other parameter definitions and values are listed in Table 2.

The gross and net primary production $\left(\mathrm{mmol} \mathrm{N} \mathrm{m}^{-2}\right)$ of ice algae for each case are calculated as below:

$$
\begin{aligned}
\mathrm{GPP}^{A i} & =\int \mathrm{Ai} G^{A i} d z d t, \\
\mathrm{NPP}^{A i} & =\int \mathrm{Ai}\left(G^{\mathrm{Ai}}-R^{A i}\right) \mathrm{d} z \mathrm{~d} t .
\end{aligned}
$$

The water and ice exchanges include nutrients and ice algae. The ice algae that are released into water sink quickly to the $6 \mathrm{~m}$ deep bottom (out of the model domain) in 1.5 days at a $4 \mathrm{md}^{-1}$ rate, equivalent to the maximum sinking rate of diatoms in water (Eslinger and Iverson, 2001). During their stay in the water, the ice algae are modeled as pelagic diatoms, which grow more slowly than ice algae at low light intensities, because data presented by Horner and Schrader (1982) indicate that algal cells found in the water column and benthos originating from the ice were not healthy. The skeletal ice layer in the model is $2 \mathrm{~cm}$ and model resolution in the water is $2 \mathrm{~m}$. The model time-step is $2 \mathrm{~min}$ and the simulation duration is from 1 March to 30 June of 2002 and 2003.

In the standard run for 2002 and 2003, the initial conditions for both physical and biological variables (seaice thickness, snow depth, water temperature, nutrient concentrations, ice algae and phytoplankton concentrations) are set to the observed values; Equation (11a) is used during ice growth and Equation (11b) during ice melt. Because nutrients were not observed in 2002, the 2003 nutrient data in water $\left(9\right.$ and $1 \mathrm{mmolm}^{-3}$ for $\mathrm{NO}_{3}$ and $\mathrm{NH}_{4}$, and $21 \mathrm{mmol} \mathrm{Si} \mathrm{m}^{-3}$ for Si on 1 March) were used instead. Model results were not sensitive to sea-ice nutrient concentrations because of the small amount of nutrients in the ice compared to the water column, and thus nutrients in ice were set to be the same as in water. Since we focus on identifying and quantifying the environmental factors controlling the sea-ice ecosystem, only the following sensitivity studies were chosen to be discussed.

We conducted five sensitivity studies for 2002: (1) doubling initial ice-algal biomass (Ai); (2) doubling light intensity; (3) doubling initial nutrient concentrations; (4) using Equation (11a) for both the ice growth and melt period; and (5) setting photoacclimation of pelagic diatoms to sea-icealgal photosynthetic parameters. There is only one sensitivity case for 2003: (6) adjusting snow depth to zero from 1 to 27 April and adding $25 \mathrm{~cm}$ of snow depth to the observed snow depth from 28 April to 17 May.

Among the above studies, light intensity and nutrients have been shown to be important limiting factors through observations and modeling in other polar ice-algal habitats (Arrigo and others, 1993; Lavoie and others, 2005). Initial ice-algal biomass is crucial as seeding population for the ice-algal bloom. Sensitivity study 4 was chosen to justify the use of Equation (11b) instead of (11a) during ice melting. Sensitivity studies 5 and 6 are designed to understand the model-data discrepancies in the phytoplankton biomass in 2002 and ice-algal biomass in 2003.

\section{MODEL RESULTS AND DISCUSSION Ice algae and phytoplankton for 2002}

The simulated ice-algal biomass for the standard case and sensitivity study cases 1-5 for 2002 are compared with observations in Figure $6 a-f$. The modeled time series of icealgal biomass for the standard case (Fig. 6a) was supported strongly by the observations. The sensitivity studies demonstrated physical and biological factors that can change the bloom in various ways.

Increasing initial ice-algal biomass led to faster ice-algal biomass accumulation in the sea ice, but the impacts 

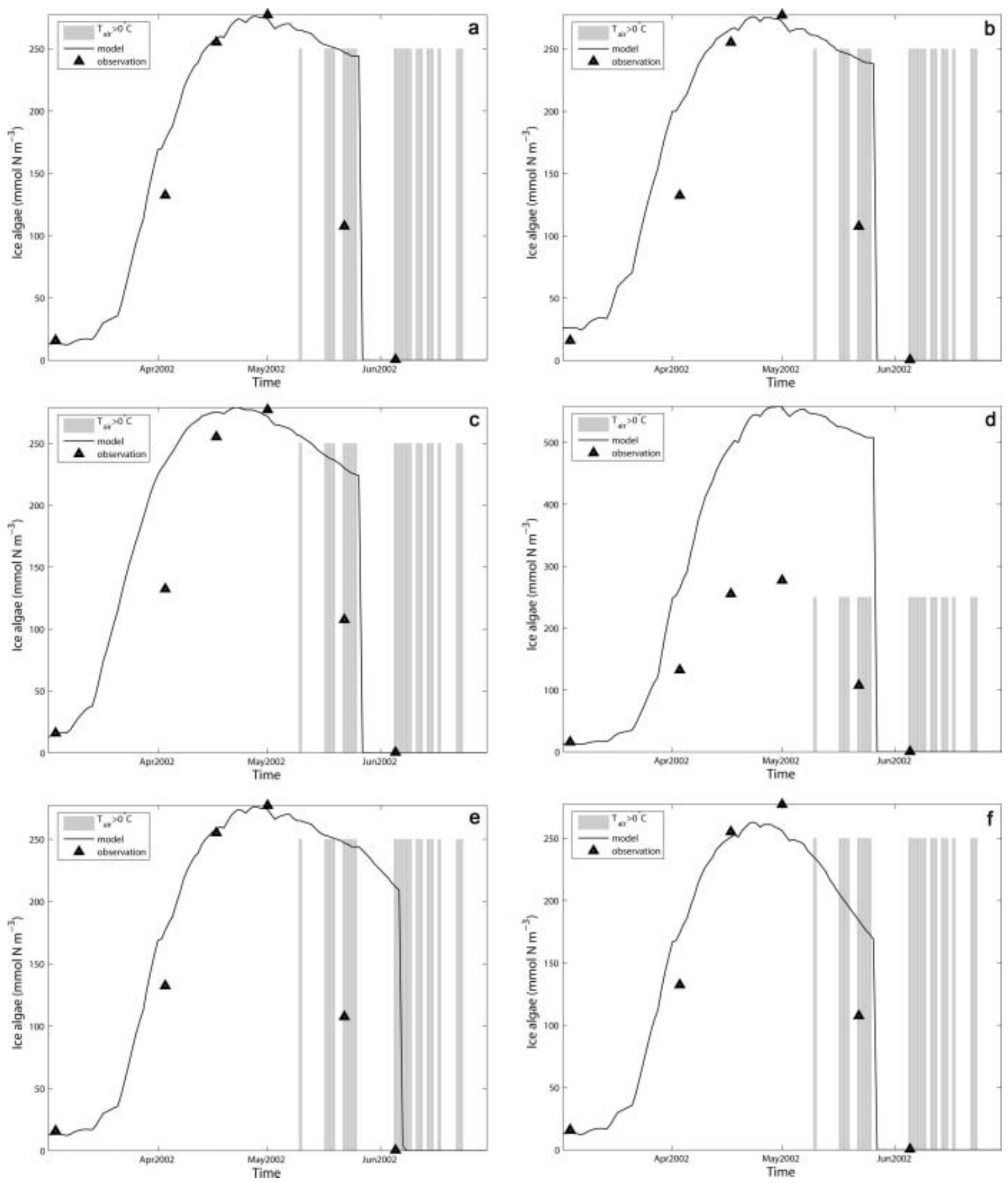

Fig. 6. Observed and simulated ice algae in 2002 for (a) standard run; (b) case 1: doubling initial $\mathrm{Ai}$; (c) case 2: doubling light; (d) case 3: doubling initial nutrients concentration; (e) case 4: using Equation (11a) for both ice growth and melting period; and (f) case 5: setting photoacclimation of diatom to that of sea-ice algae.

lessened near the bloom peak and diminished afterwards (Fig. 6b). Likewise, doubling light intensity prompted the bloom to start earlier; in addition, the bloom was slightly stronger, but the decline after the peak was sharper (Fig. 6c).

Doubling initial nutrient concentrations did not produce much difference in the early stage of the bloom but significantly shifted the magnitude of the bloom upwards, a shift that lasted until the rapid decline in late May (Fig. 6d). The initial nutrient concentrations in the water column dominated this change, while the initial nutrient concentrations in the sea ice had a negligible effect since the volume of water in the water column is overwhelmingly larger than that of the $2 \mathrm{~cm}$ skeletal ice layer.

Since there was a 10 day period of temperature greater than $0^{\circ} \mathrm{C}$ from late May to early June, using Equation (11a) for both the ice growth and melt periods delayed the timing of the ice-algal decline in the model by 10 days (Fig. 6e). This emphasized that the dramatic ice-algae decline was triggered by surface meltwater flushing. Nevertheless, the results are still not sufficient to prove that Equation (11b) is superior to (11a) in the ice melt period, because other potential mechanisms might also have contributed to this 

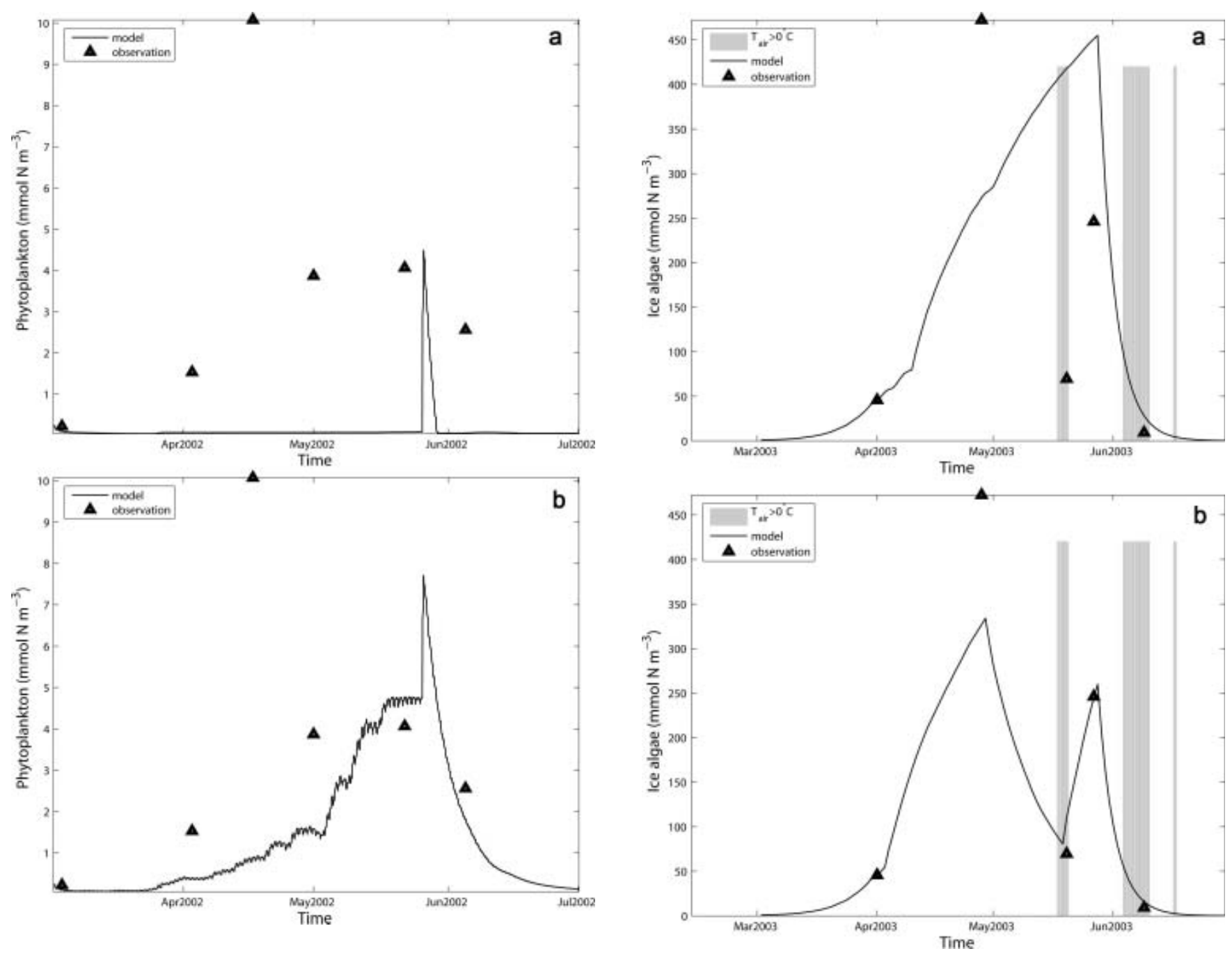

Fig. 7. Observed and simulated phytoplankton in 2002 for (a)standard run; and (b) case 5: diatom grows as ice algae.

process, such as local heating due to enhanced light absorption in the high-density algal layer, or loss of algal attachment due to melting or under-ice currents. Thus, more observations are needed to fully understand this process.

The phytoplankton bloom at Barrow usually does not start until ice break-up is underway and light is available to the cells in the water column (Horner and Schrader, 1982). However, relatively high phytoplankton biomass was observed during the ice-algal bloom period in 2002, although not in 2003. Possible explanations for this occurrence include horizontal advection of phytoplankton from nearby open water since leads may have formed just a few kilometers away along the boundary of the Barrow fast ice. Other possibilities could be a release of ice algae from the skeletal layer into the water column, or the presence of a species of diatom in the water that can grow in low light as efficiently as ice algae. This latter supposition was tested in case 5 (Fig. 6f).

In case 5 (Fig. 7b), phytoplankton begin to accumulate much earlier and faster than in the standard case (Fig. 7a). Neither case matches the maximum value observed in midApril; however, the model results shown in Figure $7 \mathrm{~b}$ match the observations more closely. The pulse in modeled phytoplankton biomass displayed in Figure 7 a was related to the ice algae released into the water that then sank to the bottom. Data presented by Horner and Schrader (1982)

Fig. 8. Observed and simulated ice algae in 2003 for (a) standard run; and (b) case 6: adjusting snow depth to zero from 1 to 27 April and adding $25 \mathrm{~cm}$ of snow depth from 28 April to 17 May.

indicate that algal cells found in the water column and benthos originating from the ice were not healthy and thus the high productivity reported in the water column at the end of the ice-algal bloom did not last.

\section{Ice algae and phytoplankton for 2003}

The model results for the standard case (Fig. 8a) matched the observed early growth and late decline of the ice algae and reached the same magnitude of peak ice-algal biomass, but missed the timing of the peak at the end of April and the sudden drop in mid-May. There are two possible reasons for the discrepancies from mid-April to mid-May. One is the 'biomodal pattern' hypothesis described by Alexander and others (1974) and Horner and Schrader (1982): the high density of ice-algal biomass associated with the first peak caused high light absorption and consequently local melting-off of the loose bottom ice. Another possibility is that combining the IARC and IMS site samples in 2003, even though these sites are in very close proximity (Fig. 1), may have contributed to higher spatial and temporal variations of the data in 2003 . The spatial variability of sampling sites can produce $>20 \%$ of the variances (or uncertainty) of ice-algal biomass as observed by APL (C. Krembs, unpublished data), especially when the algal biomass is high. 

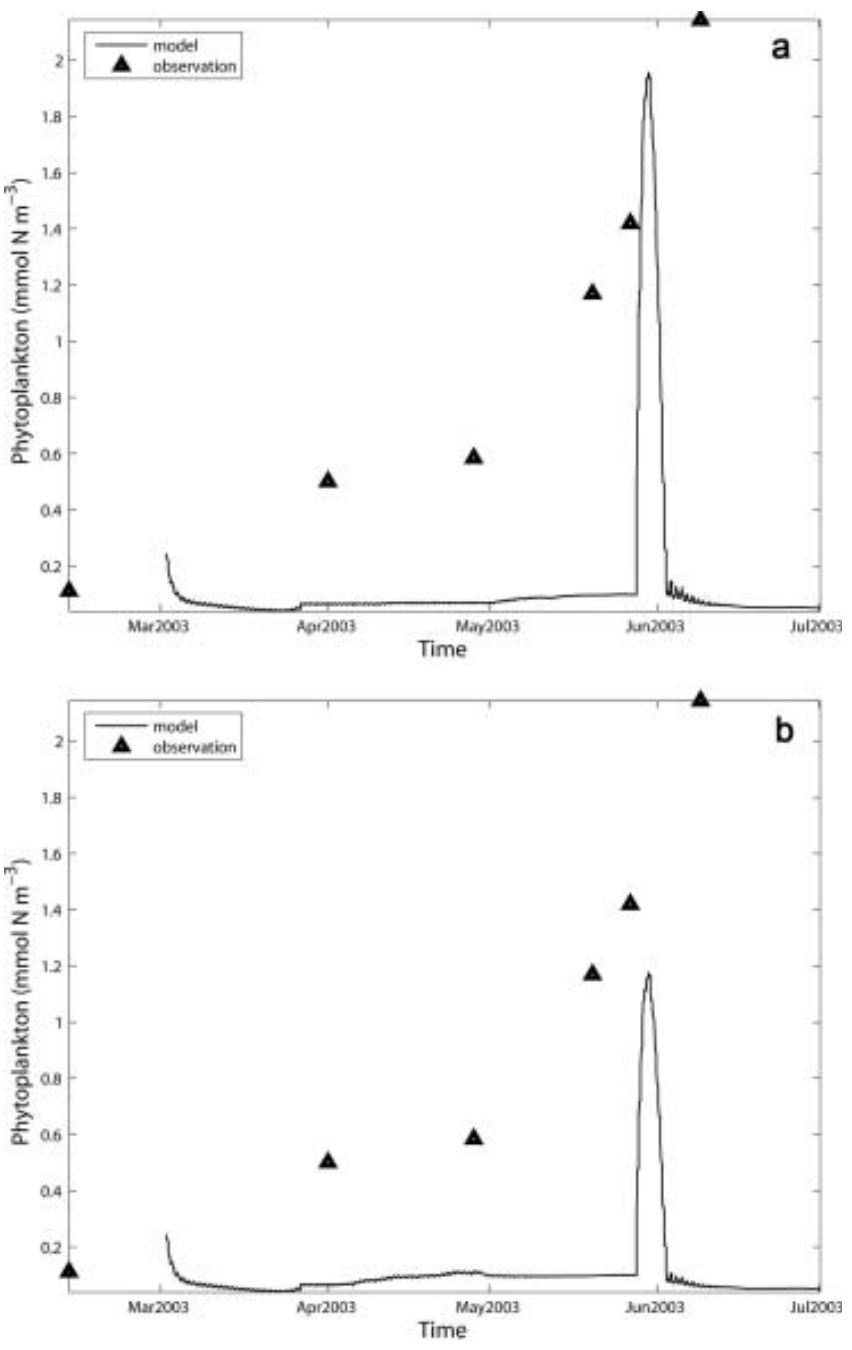

Fig. 9. Observed and simulated phytoplankton in 2003 for (a) standard run; and (b) case 6: adjusting snow depth to zero from 1 to 27 April and adding $25 \mathrm{~cm}$ of snow depth from 28 April to 17 May.

Case 6 is designed for seeking a possible explanation for the discrepancy seen in the standard case using measured snow depth. Figure $8 \mathrm{~b}$ demonstrates how light intensity can change the ice-algal bloom, and results in a closer match with observations than in the standard case. In this case, we adjust the snow depth to be 0 from 1 to 27 April, and add $25 \mathrm{~cm}$ of snow depth (test calculations show that adding more than $25 \mathrm{~cm}$ will not produce more sensible changes) from 28 April to 17 May. The results show that low snow depth accelerates bloom, and high snow depth causes the ice-algal biomass to decrease. Although case 6 is defined as adjustments in snow depth, other factors that can possibly contribute to the discrepancy in the standard case should also be represented in terms of influencing light intensity (e.g. sediments in the ice, storms, fog, cloud cover). Since even with the enhanced light in case 6 the ice-algal biomass did not reach the peak value observed on 28 April, it is more likely that the spatial variability, the second reason mentioned in the previous paragraph, would account for the discrepancies.

The modeled phytoplankton biomass (Fig. 9a) was low before mid-May and then jumped dramatically when ice algae were flushed into the water in late May and early June. The modeled maximum phytoplankton biomass reached a level similar to that observed. The phytoplankton biomass in case 6 (Fig. 9b) showed a pattern similar to that of the standard case (Fig. 9a), except for an earlier start of ice algae release into water and thus a smaller jump in late May to early June.

\section{Ice-algal primary production and export to the benthos for 2002 and 2003}

Gross and net ice-algal primary production and accumulated ice algae exported to the benthos (6 m deep) for 2002 and 2003 are tabulated and compared to the standard case in Table 3. Annual ice-algae primary production in the nearby Alaskan Arctic has been estimated with in situ data to be $5 \mathrm{~g} \mathrm{C} \mathrm{m}^{-2}$ off Barrow (Alexander and others, 1974), $1 \mathrm{~g} \mathrm{C} \mathrm{m}^{-2}$ in Prudhoe Bay (Horner and others, 1974), $1.7 \mathrm{~g} \mathrm{C} \mathrm{m}^{-2}$ in the offshore Beaufort Sea (Schell, 1980) and $0.7-0.9 \mathrm{~g} \mathrm{C} \mathrm{m}^{-2}$ in near-shore regions of the Beaufort Sea (Horner and Schrader, 1982). The model estimates of net primary production during the growing season in this study are $1.2-1.7 \mathrm{~g} \mathrm{C} \mathrm{m}^{-2}$ for 2002 and 2003, respectively, within the range of the previous estimates, but two to three times less than the highest estimate of $5 \mathrm{~g} \mathrm{C} \mathrm{m}^{-2}$ off Barrow (Alexander and others, 1974). One reason cited by Alexander and others (1974) for the relatively high estimate of $5 \mathrm{~g} \mathrm{C} \mathrm{m}^{-2}$ off Barrow was that the samples were taken from plowed areas (a road was plowed for convenience and transportation in 1972) where more light penetrated through the ice than at a snow-covered site nearby.

Sensitivity studies show that initial ice-algal biomass has little effect on the overall primary production, while doubled light resulted in a $2.7 \%$ increase in NPP ${ }^{A i}$. NPP ${ }^{A i}$ was found to increase almost proportionally to the initial nutrient concentrations in the water column (case 3). A bloom in phytoplankton (if it occurs as in case 5) would compete for nutrients with the ice algae and would lead to reduction in $\mathrm{NPP}^{\mathrm{Ai}}$. About $40-50 \%$ of the $\mathrm{NPP}^{\mathrm{Ai}}$ was exported to the benthic layer in this modeling study due to the short sinking time from the ice bottom to the sea floor at $6 \mathrm{~m}$ depth. This is qualitatively comparable to various observations indicating that most of the productivity of the ice ecosystem is released from the bottom of the ice and is subsequently exported to the underlying water (e.g. Smith and others, 1988; Taguchi and others, 2000; Ikeya and others, 2001). The model results from a coupled ice-ocean ecosystem model of Saroma lake (Nishi and Tabeta, 2005) also revealed that ice algae released from the ice were rapidly exported because of their high sinking speed and the shallow depth of the lake.

\section{CONCLUSIONS}

Based on the above observations and model results, we propose a three-stage ice-algal bloom with different dominant controls at each stage: (1) onset and early slow growth stage before mid-March, when growth is limited by day length and light intensity; (2) fast growth stage in April with increasing light intensity until nutrients are exhausted; and (3) dramatic decline stage after late May as ice algae are flushed out of the ice bottom and ice-algal growth is limited by nutrients. Stages 2 and 3 are either (1) separated by a transition period when nutrients are exhausted before ice melting starts to dramatically flush out ice algae, or (2) directly connected by ice melting. This transition period of steady plateau or slow decline of algal biomass was evident from late April to mid-May 2002, similar to the stable 
Table 3. Gross and net sea-ice-algal primary production $\left(\mathrm{GPP}^{\mathrm{Ai}}, \mathrm{NPP}^{\mathrm{Ai}}\right)$ and accumulated ice-algal export to the benthos for each case during the growing season from 1 March to 30 June. All units have been converted to $\mathrm{g} \mathrm{C} \mathrm{m}^{-2}$ using the ratios in Table 2

2002

2003

\begin{tabular}{lcccccccc} 
& Standard & Case 1 & Case 2 & Case 3 & Case 4 & Case 5 & Standard & Case 6 \\
\hline GPP $^{\mathrm{Ai}}$ & 3.25 & 3.39 & 3.51 & 6.24 & 3.63 & 2.86 & & 4.06 \\
NPP $^{\mathrm{Ai}}$ & 1.17 & 1.17 & 1.20 & 2.33 & 1.20 & 0.95 & 2.75 \\
Benthic & 0.47 & 0.46 & 0.43 & 0.99 & 0.41 & 0.33 & 0.82 & 0.47 \\
\hline
\end{tabular}

concentrations of $\mathrm{Chl}$ a that were observed and simulated in November and December in the Antarctic fast ice due to nutrient exhaustion (Arrigo and others, 1993). The absence of this transition period in the 2003 simulation implies that this interim period is unstable and may be broken off more quickly or totally bypassed by a dramatic transition from ice growth to melt. This also explains why the in situ experiments of light and nutrient enrichment in 2003 (Lee, 2005) showed light limitation only, i.e. no nutrient limitation.

The sensitivity studies showed that doubling initial nutrient concentrations in 2002 resulted in a dramatic increase in ice-algal biomass; doubling light or doubling initial ice-algal concentration caused the bloom onset to occur earlier; and a change of the water-ice transport equation from (11a) to (11b) during the ice-melting period is essential to correctly model stage 3 . The model results in 2002 demonstrated that it is the nutrient supply in the water column that determined ice-algal net primary production and export to the benthos over the spring bloom period. Other factors (light intensity, initial ice-algal concentration, and water-ice interface transport) will change the timing of the bloom, but will not significantly change the ice-algal net primary production and export to the benthos. But 2003 showed another scenario in which variations of light intensity (possibly caused by snow-depth changes, fog or storm weather, etc.) were dominant before ice melting. These model results provide evidence that environmental changes that alter nutrient concentrations or change the light regime (e.g. changes in river discharge, snow cover and seaice extent) will have complicated influences on the icewater ecosystem. These influences may cascade through the marine ecosystem to affect the food web and hence biogeochemical cycling in the Arctic.

Phytoplankton biomass usually remains low during ice cover and then blooms after the ice melts, as observed in 2003 and by Alexander and others (1974). An unexpected 'phytoplankton bloom' under the ice in 2002 calls for more observations to investigate the underlying mechanisms, either by local growth or by advection from leads further offshore. The nature of the horizontal ice-algae distribution, i.e. patchiness and continuity, demands a multi-category sea-ice model (e.g. Wang and others, 2005) to extend the $1-\mathrm{D}$ ice ecosystem model to the whole Arctic region.

\section{ACKNOWLEDGEMENTS}

IARC, University of Alaska Fairbanks, supported this study through the JAMSTEC (Japan Agency for Marine-Earth Science and Technology)-IARC Research Agreement. This study was partially supported by the Mineral Management Service/Coastal Marine Institute (MMS/CMI) fund awarded to J. Wang. The work of R.R. Gradinger was partially funded through US National Science Foundation (NSF) grant 0125464 and CMI grant TO 85242. We are grateful to $\mathrm{H}$. Eicken and $\mathrm{C}$. Krembs for providing snow- and icethickness observation data.

\section{REFERENCES}

Alexander, V., R. Horner and C. Clasby. 1974. Metabolism of Arctic sea ice organisms. Inst. Mar. Sci. Alaska Rep. R74-4.

Arrigo, K.R. 2003. Primary production in sea ice. In Thomas, D.N. and G.S. Dieckmann, eds. Sea ice: an introduction to its physics, biology, chemistry and geology. Oxford, Blackwell Science, 143-183.

Arrigo, K.R. and C.W. Sullivan. 1992. The influence of salinity and temperature covariation on the photophysiological characteristics of Antarctic sea ice microalgae. J. Phycol., 28(6), 746-756.

Arrigo, K.R. and C.W. Sullivan. 1994. A high-resolution bio-optical model of microalgal growth: tests using sea-ice algal community time-series data. Limnol. Oceanogr., 39(3), 609-631.

Arrigo, K.R., J.N. Kremer and C.W. Sullivan. 1993. A simulated Antarctic fast ice ecosystem. J. Geophys. Res., 98(C4), 6929-6946.

Arrigo, K.R., D.L. Worthen, M.P. Lizotte, P. Dixon and G. Dieckmann. 1997. Primary production in Antarctic sea ice. Science, 276(5311), 394-397.

Dieckmann, G.S. and H.H. Hellmer. 2003. The importance of sea ice: an overview. In Thomas, D.N. and G.S. Dieckmann, eds. Sea ice: an introduction to its physics, biology, chemistry and geology. Oxford, Blackwell Science, 1-21.

Eicken, H., T.C. Grenfell, D.K. Perovich, J.A. Richter-Menge and K. Frey. 2004. Hydraulic controls of summer Arctic pack ice albedo. J. Geophys. Res., 109(C8), C08007. (10.1029/ 2003JC001989.)

Eslinger, D.L. and R.L. Iverson. 2001. The effects of convective and wind-driven mixing on spring phytoplankton dynamics in the Southeastern Bering Sea middle shelf domain. Continental Shelf Res., 21(6-7), 627-650.

Eslinger, D.L. and 7 others. 2001. Plankton dynamics: observed and modelled responses to physical conditions in Prince William Sound, Alaska. Fish. Oceanogr., 10, Suppl. 1, 81-96.

Gosselin, M., M. Levasseur, P.A. Wheeler, R.A. Horner and B.C. Booth. 1997. New measurements of phytoplankton and ice algal production in the Arctic Ocean. Deep-Sea Res. II, 44(8), 1623-1625.

Gradinger, R. 1999. Integrated abundance and biomass of sympagic meiofauna in Arctic and Antarctic pack ice. Polar Biol., 22(3), 169-177.

Gradinger, R.R. and B.A. Bluhm. 2004. Susceptibility of sea ice biota to disturbance in the shallow Beaufort Sea. Phase 1: biological coupling of sea ice with the pelagic and benthic realms. Coast. Mar. Inst. Alaska Ann. Rep. 10, 70-78.

Hegseth, E.N. 1992. Sub-ice algal assemblages of the Barents Sea: species composition, chemical composition, and growth rates. Polar Biol., 12(5), 485-496. 
Horner, R. and G.C. Schrader. 1982. Relative contribution of icealgae, phytoplankton, and benthic microalgae to primary production in nearshore regions of the Beaufort Sea. Arctic, 35, 485-503.

Horner, R.A., K.O. Coyle and D.R. Redburn. 1974. Ecology of the plankton of Prudhoe Bay, Alaska. Inst. Mar. Sci. Alaska Rep. R74-2.

Ikeya, T., K. Kikuchi-Kawanobe and S. Kudoh. 2001. Floristic examination of diatom assemblage in the dim light-environment of water column and sea ice, Saroma Ko lagoon, Hokkaido, Japan. Polar Biosci., 14, 33-44.

Jin, M., C.J. Deal, J. Wang, N. Tanaka and M. Ikeda. 2006. Vertical mixing effects on the phytoplankton bloom in the southeastern Bering Sea midshelf. J. Geophys. Res., 111(C3), C03002. (10.1029/2005JC002994.)

Kirst, G.O. and C. Wiencke. 1995. Ecophysiology of polar algae. J. Phycol., 31(2), 181-199.

Lavoie, D., K. Denman and C. Michel. 2005. Modeling ice algal growth and decline in a seasonally ice-covered region of the Arctic (Resolute Passage, Canadian Archipelago). J. Geophys. Res., 110(C11), C11009. (10.1029/2005JC002922.)

Lee, S.H. 2000. Current primary production rates of the western Arctic Ocean estimated by stable carbon and nitrogen isotope tracers. (PhD thesis, University of Alaska Fairbanks.)

Michel, C., T.G. Nielsen, C. Nozais and M. Gosselin. 2002. Significance of sedimentation and grazing by ice micro- and meiofauna for carbon cycling in annual sea ice (northern Baffin Bay). Aquat. Microbial Ecol., 30(1), 57-68.

Nishi, Y. and S. Tabeta. 2005. Analysis of the contribution of ice algae to the ice-covered ecosystem in Lake Saroma by means of a coupled ice-ocean ecosystem model. J. Mar. Syst., 55(3-4), 249-270.

Perovich, D.K. 1996. The optical properties of sea ice. CRREL Monogr. 96-1.

Perovich, D.K., T.C. Grenfell, J.A. Richter-Menge, B. Light, W.B. Tucker, III and H. Eicken. 2003. Thin and thinner: ice mass balance measurements during SHEBA. J. Geophys. Res., 108(C3), 8050. (10.1029/2001JC001079.)

Schell, D.M. 1980. Food web and nutrient dynamics studies in nearshore Alaska Beaufort Sea waters. Environ. Assess. Alaskan Continent. Shelf, Annu. Rep., 2, 467-513.

Schnack-Schiel, S.B. 2003. The macrobiology of sea ice. In Thomas, D.N. and G.S. Dieckmann, eds. Sea ice: an introduction to its physics, biology, chemistry and geology. Oxford, Blackwell Science, 211-239.

Smith, R.E.H., J. Anning, P. Clément and G.F. Cota. 1988. Abundance and production of ice algae in Resolute Passage, Canadian Arctic. Mar. Ecol. Progr. Ser., 48, 251-263.

Taguchi, S., F. Satoh, S. Hamaoka, M. Ikeda, M. Ishikawa and K. Shirasawa. 2000. Effect of ice algal community on the increase of chlorophyll a concentration during spring in coastal water of the Sea of Okhotsk. Polar Biosci., 13, 1-14.

Vézina, A.F., S. Demers, I. Laurion, T. Sime-Ngando, S.K. Juniper and L. Devine. 1997. Carbon flows through the microbial food web of first-year ice in Resolute Passage (Canadian High Arctic). J. Mar. Syst., 11(1-2), 173-189.

Wada, E. and A. Hattori. 1971. Nitrite metabolism in the euphotic layer of the central North Pacific Ocean. Limnol. Oceanogr., 16(5), 766-772.

Wakatsuchi, M. and N. Ono. 1983. Measurements of salinity and volume of brine excluded from growing sea ice. J. Geophys. Res., 88(C5), 2943-2951.

Wang, J., C. Deal, Z. Wan, M. Jin, N. Tanaka and M. Ikeda. 2003. User's guide for a Physical-Ecosystem Model (PhEcoM) in the subpolar and polar oceans, version 1. Int. Arct. Res. Cent.-Front. Res. Syst. Global Change Tech. Rep. 03-01.

Wang, J., Q. Liu, M. Jin, M. Ikeda and F.J. Saucier. 2005. A coupled ice-ocean model in the pan-Arctic and North Atlantic Ocean: simulation of seasonal cycles. J. Oceanogr., 61(2), 213-233.

Werner, I. 1997. Grazing of Arctic under-ice amphipods on sea-ice algae. Mar. Ecol. Progr. Ser., 160, 93-99. 